\section{PLASTICS FOR THE PRACTICAL MAN}

\section{Polyurethanes}

By Bernard A. Dombrow. (Reinhold Plastics Applications Series.) Pp. ix + 176. (New York: Reinhold Publishing Corporation; London: Chapman and Hall, Ltd., 1957.) 4.50 dollars.

\section{Polyamide Resins}

By Don E. Floyd. (Reinhold Plastics Applications Series.) Pp. viii +230 . (New York : Reinhold Publishing Corporation; London: Chapman and Hall, Ltd., 1958.) 4.50 dollars.

\section{Plastic Sheet Forming}

By Robert L. Butzko. (Reinhold Plastics Applications Series.) Pp. ix +181 . (New York : Reinhold Publishing Corporation; London: Chapman and Hall, Ltd., 1958.) 4.50 dollars.

\section{Cellulosics}

By Walter D. Paist. (Reinhold Plastics Applications Series.) Pp. xi +270 . (New York: Reinhold Publishing Corporation; London: Chapman and Hall, Ltd., 1958.) 5.75 dollars.

\section{Fluorocarbons}

By Merritt Allen Rudner. (Reinhold Plastics Applica tions Series.) Pp. $x+238$. (New York: Reinhold Publishing Corporation; London: Chapman and Hall, Ltd., 1958.) 5.75 dollars.

" THE Modern Plastics Encyclopedia" for 1958 lists 102 books on plastics and high polymers published since 1950. To this literature, a new series of monographs has been added (Reinhold Plastics Application Series) of which six have been issued while ten more are in preparation. Their appearance coincides with a recent decision of the Plastics Institute to make its set of eleven titles in the Plastics Monograph series available to the public through an arrangement with Messrs. Iliffe.

Any protest at this profusion of books on plastics must be tempered by the awareness of much disagreement existing between the experts as to the very nature of plastics as displayed at the recent Polymer Tribunal. In any event, any new book may be welcomed if it largely comprises new material or a novel presentation, and it is in this spirit that the present series may be reviewed.

In "Polyurethanes", a brief account of their chemistry is followed by chapters on foams, rubbers and surface-coating and adhesive applications. The book makes clear which are the commercially important raw materials and the manner in which the systems function in diverse applications. It contains a useful account of polyurethanes derived from castor oil, and hindered and reversible systems and, despite the absence of serial references, should have a reasonably wide appeal.

"Polyamide Resins" is written with a chemical slant, and serial references are given to published work. The book contains little that is new about fibre-forming polyamides and may be valued principally for the information it gives on the novel 'Versamid' dimeric fatty acid/polyalkylene amine polyamides and their blends with epoxy resins, with which the author is specially familiar by virtue of his association with General Mills Inc.

The reader of "Plastic Sheet Forming" will be impressed with the scope of this versatile technique by the long list of applications assembled. Nineteen variations of the process illustrated by easy-to-follow diagrams and an account of commercially available equipment, including cost estimates, makes it possible to recommend this as a very useful practical guide to those contemplating the use of the sheet-forming process.

In contrast with the three books listed above, the author of "Cellulosies" has had to deal with a subject in which there is a very considerable literature. The presentation ranges from fabrication techniques for spectacle frames to the dyeing of woven fabrics. In attempting to cover all outlets for cellulose and its derivatives, the book is of proportionately reduced value to the student of plastics. Neither references nor a separate bibliography are given. Table 3.5 requires correction.

The title of "Fluorocarbons" is somewhat misleading, for the book contains no mention of materials other than polymers of tetrafluorethylene and monochloro trifluorethylene. Even on these, there is little information not normally available from sales and technical bulletins. The term molecular weight is often used in the wrong sense, and a chapter on the chemistry of fluorocarbons (written in collaboration with Claude Bunnell) is marred by misprints.

In an ostensibly uniform series of monographs, a bad impression created by any one book tends to prejudice the reader against the remainder of the series. Such a temptation should be resisted and, as this review shows, each monograph should be appraised on its own merits. One overall criticism, which is often made in regard to American publications, is that the price per book will be considered high in Britain in relation to the value. S. H. Pinner

\section{MAMMALIAN HAIR}

\section{The Biology of Hair Growth}

Edited by William Montagna and Richard A. Ellis. Pp. xvii +520. (New York : Academic Press, Inc.; London: Academic Books, Ltd., 1958.) 15 dollars.

7 HIS book, equivalent to proceedings of the Conference on Hair Growth held in London in 1957 , is a revelation of progress and promise. Those working on hair will need no encouragement to keep this book always at hand. It reports a modern breakthrough, by new techniques and experiment, largely in young branches of old sciences, often concerned with very minute structure and tiny quantities. Hair is very favourable material for relating biochemistry to morphology. Though much remains to be discovered, Montagna may reasonably claim, after surveying recent advances which emphasize how precise is the control of the intense activity of the follicle, that, "the understanding of the prime forces that guide and control hair growth cannot be far off".

As an organ, the hair follicle corresponds in convenience with Protozoa among animal types, and examples follow of phenomena and principles of which bio-scientists in other fields may care to take note. Cell division is an all-or-none reaction, and even the death of the animal does not arrest it (Bullough, on mitosis). Some treatments inhibit initiation of growth, but have no effect on follicles already growing (Mohn, and Montagna's summary). An intricate balance of many hormones is required for the normal occurrence of the periodic waves of spontaneous replacement in the rat (Mohn). The response of follicles to treatments depends on the phase of the 